\title{
Availability of the Application Ingredients of Activity-Based Costing System in Jordanian Tourism Companies
}

\author{
Enas Fakhri Mohammad Abu-Eker \\ Department of Administration and Financial Sciences \\ E-mail: qtaybah882003@yahoo.com \\ Dr. Mohammad Nayef ALsarayreh \\ Educational Science and Social Department \\ AlBalqa Applied University, Karak, Jordan \\ E-mail: mohammad_n_k_s@yahoo.com \\ Muneer Mohamad Falah Jaradat \\ Department of administration and financial sciences \\ AlBalqa Applied University, Aqaba, Jordan \\ E-mail: mune_2000@yahoo.com \\ Ziad Odeh Ebniah Al Amaideh \\ Management and Financial Science branch \\ AlBalqa Applied University, Karak, Jordan \\ E-mail: sameeralamro@yahoo.com
}

Received: September 22, 2011 Accepted: October 16, $2011 \quad$ Published: January 1, 2012

doi:10.5296/jmr.v4i2.1612 URL: http://dx.doi.org/10.5296/jmr.v4i2.1612

\begin{abstract}
The study aimed to show the extent of existence of the application ingredients of Activity-based costing system in Jordanian tourism companies. The study found that the main ingredients is existed in these companies, the management perspective generally support its application, but it rather believe that the application costs exceed its benefits and the management fears from not applying it efficiently. The human cadres and the available
\end{abstract}




\section{Macrothink}

Journal of Management Research ISSN 1941-899X

2012, Vol. 4, No. 2

technology support its application except that the available software packages do not cover all the activities, and there is no continuous technical support to the users of the equipment and software. It was also concluded that the nature of the business of Jordanian tourism companies support the application of this system.

Keywords: Tourism companies, Costing system, Technology, Management 


\section{Introduction}

Rapid developments in communications and information technology, as well as shifts in the international economic relations represented by clusters and agreements have transformed the world into one market, accessible to all; this has led to increased competition between organizations of the world as a whole. It draws the attention of management to cost elements in terms of valuing it strictly and managing in away that allows it to be reduced in order to increase competitiveness, so the traditional systems for cost measurement are incapable of providing appropriate information which are adapted to these requirements, as there were doubts about the accuracy of such information which may be misleading for the decision makers as this new environment has significant impact on the structure and the behavior of the costs. The attention to developing costs systems has increased in order to meet the needs of management under the new environment, so cost system based on activities is one of the many modern entries that have emerged which exceeded many criticisms of traditional systems of measuring costs.

The implementation of activity-based costing system needs many ingredients and requirements: first convinced management of this system, which requires implementation costs more than that for traditional systems, however, its importance in the exact determination of costs justify these additional costs, particularly if the businesses of the organization are characterized by complexity and diversity in its consumption of resources and there is no direct relationship between cost elements and cost goals. This system requires qualified human cadres capable of implementation starting from establishment phase up to execution phase. Applying this system needs advanced technology regarding hardware, software, or communications network.

When activity-based costing system has been designed and developed the focus was primarily on the industrial sector. But it soon was applied in other sectors such as the service sector, which excels from other sectors of non-tangibility of its products. And tourism companies as a part of the service sector interested in determining costs for different purposes may resort to the application of this system, especially if they face competition affect their career.

\section{Previous Studies}

Durgham, 2007, The study aimed to identify the availability of the requisites of the application of activity-based costing in the Palestinian government hospitals. The study found that elements for applying this system are existed in these hospitals. The study recommended to set up separate sections for cost accounting and support it with scientifically and practically qualified human cadres. And to adopt the application of activity-based costing to access accurate cost information.

Katja, 2002, This study examined ways to control costs, and concluded that the most effective ways in this area that are interested in designing pre-production costs. The researcher finds that the study stressed that according to the traditional systems of costs measurement, cost data are rarely available for product designers to be used effectively. The 
objective of the study represented in describing the possibility to use ABC to provide cost information useful for production designers in a way to provide an effective tool to assess different options for the design. The study concluded that the entrance of ABC provides a good starting point to pay more attention to product design process.

David and Li, 2003, This study examined the role that could be played by ABC under fierce global competition. The researcher finds that the study indicated that serious competition is forcing those involved in the industry to pay attention to quality, cost and time required for marketing the product through shorter marketing cycle, and the reflection of that on the different stages of the product life cycle. The study confirmed that $\mathrm{ABC}$ has become the sufficiently appropriate for accurate costing estimates of the manufactured parts of the product, so that this approach was applied with acceptable success rates. The study concluded to lay the foundations of a methodology to use $\mathrm{ABC}$ approach in a way that helps to evaluate the cost of the activities of design and development of manufactured parts.

Victoria and John, 2003, This study examined the entrance to $\mathrm{ABC}$ as a basis for improving the performance evaluation, the study indicated that this could be achieved through the provision of estimates of the costs that meet satisfactory sales conditions represented by the number of payments through which the order is produced and the number of training hours for official dealing with customers, furthermore providing estimates of useful resources in marketing activities. The study pointed that the traditional cost measurement systems assume that the marketing costs varies only at the unit level, also that systems do not give estimates to costs of many of those activities.

Abdullah, 2008, The study aimed to demonstrate the reality of applying activity-based costing system in industrial companies in Yemen and the factors affecting it. The study found that $24 \%$ of the Yemeni industrial companies, mostly large companies applied the system; the study found that the support of senior management and ownership of non accounting information is directly linked to the application of this system. The study recommended that companies that apply traditional systems need to use costing systems that helps to calculate its costs accurately and researcher proposes using activity-based cost system to achieve this.

Helles, 2007, The study aimed to demonstrate the possibility of using the accounting approach to calculating costs. This approach is based on Activity Based Costing (ABC) which is used in assessing and controlling the cost of educational services; in addition, it provides the necessary data which is used in accurate identification of administrative decision as well as the cost of services provided by universities. The study concluded that the new system can help in overcoming the problems related to the use of the traditional system in; the $\mathrm{ABC}$ helps in assessing the indirect cost and determining the average cost of each activity in accordance with the suitable cost stimulators. The ABC can overcome the problems emerging from charging on capitals. Pricing based on $A B C$ is useful in the administration of universities in the sense of raising awareness of cost. This will be reflected on employing the available resources to achieve the desired goals.

Mahmood, 2007, The study aimed to identify the reality of cost accounting systems in Palestinian companies and the nature of its use. And concluded that most pharmaceutical 
companies do not apply activity-based costing system, there is no awareness of officials in these companies to correct regulatory conditions for facilitating the application of this system. The companies face difficulties that hinder the application of the system. The study recommended the development of the perspective of the public administration towards nature and importance of the ABC System. Cost accounting department should be strengthened with the needed human competencies. And the corporate accounting should keep up with for technical developments in costing systems and the use of $\mathrm{ABC}$ to the extent necessary to keep pace with this evolution due to the consult in all advanced industrial installations.

\section{The Problem of the Study}

The problem of the study starts from inquiring the extent of Jordanian tourism companies implementation of activity-based costing system, and the availability of the ingredients of its implementation; Is management of these companies are aware and understand the importance of this system, , and do they have the human resources capable of applying this system, and whether appropriate technologies are available to be applied effectively, and whether the nature of the businesses and functions of these companies make its application a necessity.

\section{The Objective of the Study}

The study aims to describe the availability extent of ingredients for the application of activity-based costing system in Jordanian tourism companies represented in the management convictions of this system, and the availability of human resources required by the system, and the availability of sufficient technology quantitatively and qualitatively and the need extent of the nature of businesses and functions for this system.

\section{The Importance of the Study}

The importance of this study emerges from the role of activity-based costing system in the management and reduction of costs leading to greater profitability and competitiveness and thus greater capacity to continue. Also this importance is increased due to the population of the study - tourism companies- which belong to the service sector that is characterized by the scarcity of studies that attempt to link it with this system. In addition to the importance of the touristic sector from the economic side of this country, and what regional and global challenges it faces.

\section{The Population and the Sample of the Study}

Jordanian tourism companies represent the population of the study, 23 companies have been selected randomly to represent the study sample.

\section{The Study Instrument}

A questionnaire was used as an instrument to collect primary data; it was designed to measure the situation of tourism companies. 120 copies of the questionnaire were distributed on the various companies, 112 have been restored that are valid for analysis by $93 \%$. The style of the questionnaire was based on closed questions, where answers available (strongly 
agree, agree, neutral, disagree, strongly disagree). The answers were weighted following the previous grades $(5.4,3,2.1)$, respectively.

\section{The Methodology of the Study}

The study relied on descriptive analytical method, where the primary data collected from the study population were analyzed statistically to get the results related to the dimensions of the study.

\section{The Statistical Methods Used}

Several statistical measures were calculated and they are: arithmetic average, t-test, Cronbach's alpha test and standard deviation. To test hypotheses and items the standard for acceptance is that the arithmetic average must be greater than 3 and to be significant the $\mathrm{t}$-value should be greater than its tabulated value or that the observed significance level should be less than 0.05 .

\section{The Instrument Reliability}

The instrument reliability was tested using Cronbach's alpha coefficient test, it is shown from table (1) that:

- for the items of management dimension the value of alpha equals 0.84

- For the items of human cadres dimension the value of alpha equals 0.82 .

- for the items of technology dimension the value of alpha equals 0.76

- for the items of the nature of the business dimension the value of alpha equals 0.74

- for all the items combined the total value of alpha equals 0.90

All these values are higher than 0.60 which means that the instrument is reliable.

Table 1. The results of Cronbach's alpha test

\begin{tabular}{|c|c|}
\hline Dimension & The value of alpha \\
\hline Management & 0.85 \\
\hline Human cadres & 0.82 \\
\hline Technology & 0.76 \\
\hline Nature of the business & 0.74 \\
\hline total & 0.90 \\
\hline
\end{tabular}

Description of personal and functional factors of the respondents

Table (2) shows a description of the personal and functional factors of the respondents which was as follows:

Gender: the table indicates that $70.54 \%$ of respondents were males. And $29.98 \%$ were females.

Age: the largest proportion was $40.18 \%$ and belongs to the period from 35 years old to less than 45 years old, followed by the period ranged from 26 years old and less than 35 years old which 
has $25.00 \%$, at same percentage came the period that ranged greater than or equals to 45 years old and more. Finally came the period that ranged less than or equals 25 years old.

Educational level: $58.93 \%$ of respondents had an undergraduate degree, and then $22.32 \%$ representing who have diploma, followed by $9.82 \%$ of master's degree holders, while the holders of secondary school certificate were $5.36 \%$, but the lowest percentage of $3.57 \%$ was for PhDs.

Expertise: $29.98 \%$ of responders their experience ranged between 4 years and less than 7 years , and $22.32 \%$ their experience ranged between 7 years to less than 10 years, while $20.54 \%$ of the respondent their experience equals 10 years and more, $19.64 \%$ had experience between two years up to less than 4years, finally $8.04 \%$ their experience was less than two years

Job level: $44.64 \%$ of the respondents were of the staff, $34.82 \%$ of heads of departments, $15.18 \%$ of the Deputy Directors, and $5.36 \%$ of managers.

Table 2. Frequencies and percentage of the personal factors of the respondent

\begin{tabular}{|c|c|c|c|}
\hline Factor & Period & Frequency & Percentage $\%$ \\
\hline \multirow[t]{2}{*}{ Gender } & Male & 79 & 70.54 \\
\hline & Female & 33 & 29.46 \\
\hline \multirow[t]{4}{*}{ Age } & Less than or equal to 25 years old & 11 & 9.82 \\
\hline & From 26 years old to less 35 years old & 28 & 25.00 \\
\hline & From 35 years old to less 45 years old & 45 & 40.18 \\
\hline & 45 years old or greater & 28 & 25.00 \\
\hline \multirow[t]{5}{*}{ Educational level } & Secondary school certificate & 6 & 5.36 \\
\hline & Diploma & 25 & 22.32 \\
\hline & Bachelor degree & 66 & 58.93 \\
\hline & Master degree & 11 & 9.82 \\
\hline & PhDs holders & 4 & 3.57 \\
\hline \multirow[t]{5}{*}{ Expertise } & $<2$ years & 9 & 8.04 \\
\hline & From 2 years to less than 4 years & 22 & 19.64 \\
\hline & From 4 years to less than 7 years & 33 & 29.46 \\
\hline & From 7 years to less than 10 years & 25 & 22.32 \\
\hline & 10 years or greater & 23 & 20.54 \\
\hline \multirow[t]{4}{*}{ Job level } & Managers & 6 & 5.36 \\
\hline & Deputy Directors & 17 & 15.18 \\
\hline & heads of departments & 39 & 34.82 \\
\hline & Staff & 50 & 44.64 \\
\hline
\end{tabular}

\section{Exploratory Study}

In the beginning the extent of application of activity-based costing system by Jordanian tourism companies, through personal interview with those involved in 23 companies that are the most important companies which could use this system. It found that 19 companies 
applied conventional systems, and 4 companies use relatively sophisticated costing systems but did not reach the level of activity-based costing system.

\subsection{Test and Analysis of the First Hypothesis}

The management's perspective supports the application of activity-based costing in Jordanian tourism companies.

It has been shown from table (3) that all items have arithmetic averages greater than 3 and observed significance levels less than 0.05 for each one which means that it exists in a statistically significant degree, except for item (3) and item (4). Item (5) which measures the extent of management conviction of the importance of the system in improving the performance, comes first with 4.25 arithmetic average followed by item (9) which measures whether the management believe that the application of the system helps in reducing the costs of the activities, in the second rank with an arithmetic average of 4.11. In the last rank within the statistically accepted items and with an arithmetic average of 3.94 comes item (7) which measures whether the management believes that activities system helps in better interpretation of profitability.

Item (3) which has got an arithmetic average less than 3, i.e., the management does not think that the costs of application of activities system exceed its benefits. Item (4) also got an arithmetic average less than 3 , i.e., the management fears that the systems could be applied efficiently.

All items which measured the dimension of the management have an arithmetic average of 3.67 and the observed level of significance is 0.00 , i.e., it is statistically significant and so the first hypothesis is accepted, which means that the management's perspective supports the application of activity-based costing in Jordanian tourism companies. 
Table (3). Arithmetic average, standard deviation, t-value and the observed level of significance of management dimension

\begin{tabular}{|c|c|c|c|c|c|}
\hline $\begin{array}{l}\text { Item } \\
\text { No. }\end{array}$ & Item & $\begin{array}{l}\text { Arithmetic } \\
\text { average }\end{array}$ & s.d. & t-value & $\begin{array}{l}\text { Observed } \\
\alpha\end{array}$ \\
\hline 1 & $\begin{array}{l}\text { The Management is convinced of the importance of } \\
\text { activities system in determining the costs }\end{array}$ & 4.06 & 0.66 & 17.00 & 0.00 \\
\hline 2 & $\begin{array}{l}\text { Management recognizes the inadequacy of } \\
\text { traditional cost systems }\end{array}$ & 4.06 & 0.43 & 26.13 & 0.00 \\
\hline 3 & $\begin{array}{l}\text { Management thinks that the costs of applying } \\
\text { system activities outweigh its benefits }\end{array}$ & 2.32 & 0.94 & -7.63 & 0.00 \\
\hline 4 & $\begin{array}{l}\text { Management do not fear that the system cannot be } \\
\text { applied efficiently }\end{array}$ & 2.25 & 0.78 & -10.22 & 0.00 \\
\hline 5 & $\begin{array}{l}\text { The Management is convinced of the importance of } \\
\text { activities to improve system performance }\end{array}$ & 4.25 & 0.56 & 23.56 & 0.00 \\
\hline 6 & $\begin{array}{l}\text { The Management } t \text { believes that the business of the } \\
\text { organization can be divided into homogeneous } \\
\text { activities }\end{array}$ & 4.00 & 0.62 & 17.21 & 0.00 \\
\hline 7 & $\begin{array}{l}\text { Management considers that activities system help to } \\
\text { interpret profitability in a better way }\end{array}$ & 3.94 & 0.56 & 17.78 & 0.00 \\
\hline 8 & $\begin{array}{l}\text { Management considers that implementation activities } \\
\text { system increases the competitiveness ability of the } \\
\text { enterprise }\end{array}$ & 4.06 & 0.75 & 14.98 & 0.00 \\
\hline 9 & $\begin{array}{l}\text { Management considers that implementation activities } \\
\text { system helps to reduce the costs of activities }\end{array}$ & 4.06 & 0.56 & 20.15 & 0.00 \\
\hline & Total & 3.67 & 0.30 & 23.59 & 0.00 \\
\hline
\end{tabular}

\subsection{Test and Analysis of the Second Hypothesis}

The human cadres in Jordanian tourism companies support the application of activity-based costing system.

It has been shown from table (4) that all items have arithmetic averages greater than 3 and observed significance levels less than 0.05 for each one which means that it exists in a statistically significant degree, except for item (12). Item (11) which measures the ability of staff in various departments to interact with the system, comes first with 4.06 arithmetic average followed by item (15) which measures Workers ' interest in the success of what's new, in the second rank with an arithmetic average of 3.94. In the last rank within the statistically accepted items and with arithmetic average of 3.63 comes item (16) which measures the existence of enough moral and material motivation for the success of the system.

Although item (12) has got arithmetic average greater than 3.00, the observed significance level was greater than 0.05 , i.e., the Management does not hold training courses for staff members continuously and timely appropriate for keeping pace with what's new. 
All items which measured the dimension of human cadres have an arithmetic average of 3.67 and the observed level of significance is 0.00 , i.e., it is statistically significant and so the second hypothesis is accepted, which means that the human cadres in Jordanian tourism companies support the application of activity-based costing system.

Table 4. Arithmetic average, standard deviation, $t$-value and the observed level of significance of human cadres' dimension

\begin{tabular}{|c|c|c|c|c|c|}
\hline $\begin{array}{l}\text { Item } \\
\text { No. }\end{array}$ & Item & $\begin{array}{l}\text { Arithmetic } \\
\text { average }\end{array}$ & s.d. & $\mathrm{t}$-value & $\begin{array}{l}\text { Observed } \\
\alpha\end{array}$ \\
\hline 10 & $\begin{array}{l}\text { The staff concerned with costing systems is able to } \\
\text { apply the system. }\end{array}$ & 3.88 & 0.49 & 19.04 & 0.00 \\
\hline 11 & $\begin{array}{l}\text { Staff in various departments are able to interact with } \\
\text { the system }\end{array}$ & 4.06 & 0.66 & 17.00 & 0.00 \\
\hline 12 & $\begin{array}{l}\text { Training sessions are continually held for staff at the } \\
\text { appropriate time keep abreast of what's new }\end{array}$ & 3.07 & 1.06 & 0.71 & 0.48 \\
\hline 13 & $\begin{array}{l}\text { There is sufficient scientific potential for } \\
\text { accountants }\end{array}$ & 3.88 & 0.78 & 11.81 & 0.00 \\
\hline 14 & $\begin{array}{l}\text { Accountants have the advantage of adequate mental } \\
\text { skills for applying the system }\end{array}$ & 3.88 & 0.70 & 13.25 & 0.00 \\
\hline 15 & The staff is interested in the success of what's new & 3.94 & 0.83 & 11.95 & 0.00 \\
\hline \multirow[t]{2}{*}{16} & $\begin{array}{l}\text { There is enough moral and material motivation for } \\
\text { the success of the system }\end{array}$ & 3.63 & 1.00 & 6.64 & 0.00 \\
\hline & Total & 3.76 & 0.48 & 16.92 & 0.00 \\
\hline
\end{tabular}

\subsection{Test and Analysis of the Third Hypothesis}

The available technology in Jordanian tourism companies supports the application of activity-based costing system.

It has been shown from table (5) that all items have arithmetic averages greater than 3 and observed significance levels less than 0.05 for each one which means that it exists in a statistically significant degree, except for item (19) and item (24). Item (22) which measures the ability of hardware to produce and to store information, comes first with 4.08 arithmetic average followed by item (21) which measures the flexibility and the ability of hardware to cope with emergencies, in the second rank with an arithmetic average of 4.04. In the last rank within the statistically accepted items and with arithmetic average of 3.56 comes item (18) which measures the extent of modernization and development of used continuously software.

Item (19) which has got an arithmetic average less than 3, i.e., Software available does not cover all company activities. Item (24) also got an arithmetic average less than 3, i.e., ongoing technical support is not available for users of hardware and software.

All items which measured the dimension of human cadres have an arithmetic average of 3.81 and the observed level of significance is 0.00 , i.e., it is statistically significant and so the third hypothesis is accepted, which means that the available technology in Jordanian tourism companies supports the application of activity-based costing system. 
Table 5. Arithmetic average, standard deviation, $t$-value and the observed level of significance of the available technology dimension

\begin{tabular}{|c|c|c|c|c|c|}
\hline $\begin{array}{l}\text { Item } \\
\text { No. }\end{array}$ & Item & $\begin{array}{l}\text { Arithmetic } \\
\text { average }\end{array}$ & s.d. & t-value & $\begin{array}{l}\text { Observed } \\
\alpha\end{array}$ \\
\hline 17 & $\begin{array}{l}\text { There are sophisticated computer hardware and } \\
\text { software }\end{array}$ & 3.81 & 0.53 & 16.26 & 0.00 \\
\hline 18 & The software used are updated and constantly & 3.56 & 0.71 & 8.41 & 0.00 \\
\hline 19 & Available software covers all company activities & 2.90 & 1.25 & -0.83 & 0.41 \\
\hline 20 & Computers is maintained periodically & 3.88 & 0.60 & 15.38 & 0.00 \\
\hline 21 & $\begin{array}{l}\text { Computers are Flexible and able to cope with } \\
\text { emergencies }\end{array}$ & 4.06 & 0.43 & 26.13 & 0.00 \\
\hline 22 & $\begin{array}{l}\text { Computers has the capacity to produce and store } \\
\text { information }\end{array}$ & 4.06 & 0.24 & 46.25 & 0.00 \\
\hline 23 & $\begin{array}{l}\text { Computers has the ability to retrieve information } \\
\text { quickly and accurately }\end{array}$ & 3.94 & 0.56 & 17.78 & 0.00 \\
\hline 24 & $\begin{array}{l}\text { Technical support is available for users of hardware } \\
\text { and software }\end{array}$ & 2.81 & 1.13 & -1.76 & 0.08 \\
\hline \multirow[t]{2}{*}{25} & $\begin{array}{l}\text { Software is capable of delivering information to the } \\
\text { sections and departments quickly and accurately }\end{array}$ & 3.87 & 0.89 & 10.35 & 0.00 \\
\hline & Total & 3.81 & 0.53 & 16.26 & 0.00 \\
\hline
\end{tabular}

\subsection{Test and Analysis of the Fourth Hypothesis}

The Nature of the business in Jordanian tourism companies supports the application of activity-based costing system.

It has been shown from table (5) that all items have arithmetic averages greater than 3 and observed significance levels less than 0.05 for each one which means that it exists in a statistically significant degree. Item (28) which measures whether indirect costs represent a large part of the cost structure, comes first with 4.13 arithmetic average followed by item (30) which measures the difficulty in linking services activities under traditional costing systems. In the last rank within the statistically accepted items and with arithmetic average of 3.81 comes item (29) which measures The existence of joint activities for tourism services.

All items which measured the dimension of nature of the business have an arithmetic average of 3.95 and the observed level of significance is 0.00 , i.e., it is statistically significant and so the fourth hypothesis is accepted, which means that the nature of the business in Jordanian tourism companies supports the application of activity-based costing system.

Table (6). Arithmetic average, standard deviation, t-value and the observed level of significance of the nature of the business dimension

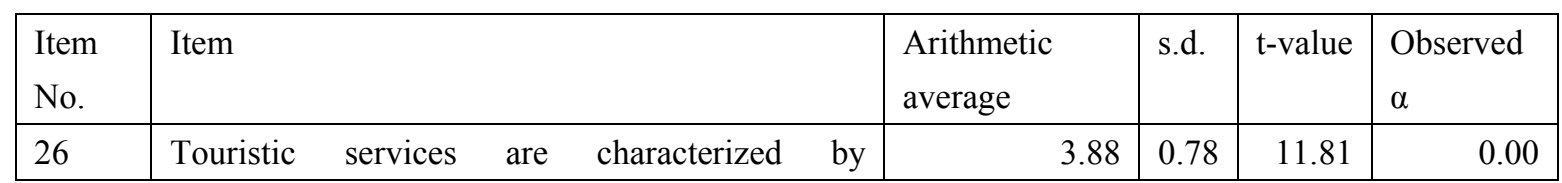




\begin{tabular}{|l|l|r|r|r|r|}
\hline & quantitative diversity & & & \\
\hline 27 & tourism services are qualitatively different & 3.94 & 0.83 & 11.95 & 0.00 \\
\hline 28 & $\begin{array}{l}\text { Indirect costs represent a large part of the cost } \\
\text { structure }\end{array}$ & 4.13 & 0.49 & 24.48 & 0.41 \\
\hline 29 & There are joint activities of tourism services & 3.81 & 0.89 & 9.71 & 0.00 \\
\hline 30 & $\begin{array}{l}\text { There is difficulty in linking services activities } \\
\text { under traditional systems cost }\end{array}$ & 4.00 & 0.62 & 17.21 & 0.00 \\
\hline & Total & 3.95 & 0.57 & 17.49 & 0.00 \\
\hline
\end{tabular}

\section{Results}

The study found the following results:

1. The management's perspective supports the application of activity-based costing in Jordanian tourism companies. As the management is convinced of the importance of the system to determine costs and improve performance, and helps to give better explanation of the profitability and increases the ability of competitiveness of the organization, and helps to reduce the costs of activities. The management is aware of the limitations of traditional cost systems, and considers that the businesses of the organization can be divided into homogeneous activities. But the management believes that the costs of application of activities system outweigh the benefits, and fears that the system could not be applied efficiently.

2. The human cadres in Jordanian tourism companies support the application of activity-based costing system. Since staff concerned with costing systems are able to apply the system, and staff in various sections are capable of interaction with this system, the accountants have possibilities of scientific and intellectual skills sufficient to apply the system, and the employees are interested in the success of what is new, and there is adequate physical and moral motives to make this system a success. But training courses for staff members are not continuously and timely held for keeping pace with what is new.

3. The available technology in Jordanian tourism companies supports the application of activity-based costing system. Where there is a sophisticated computer hardware and software, software used and are updated constantly, and hardware are maintained periodically, and Computers are Flexible and able to cope with emergencies, and Computers has the capacity to produce and store information, and Computers has the ability to retrieve information quickly and accurately, and Software is capable of delivering information to the sections and departments quickly and accurately. While software available do not cover all company activities, and ongoing technical support is not available for users of hardware and software.

4. The Nature of the business in Jordanian tourism companies supports the application of activity-based costing system. Where Touristic services are characterized by quantitative diversity and are qualitatively different, furthermore indirect costs represent a large part of the cost structure, also there are joint activities of tourism services, and there is difficulty in linking the activities under the traditional costs of systems.

\section{Recommendations}


The study recommends that:

1. Jordanian tourism companies should move to application of activity-based costing systems since the fundamental components of the application are available.

2. It is necessary for the management of Jordanian tourism companies to start in depth studying of the benefits of the application of activity-based costing system and consulting the experts to reach an accurate comparison between application costs of the system and its benefits.

3. Management of Jordanian touristic firms should not fear from implementing the system inefficiently since the essential and the necessary ingredients for its application are existed.

4. Jordanian tourism companies should hold training courses for staff members continuously and in the appropriate time to keep pace with what is new.

5. Jordanian tourism companies should provide software that covers all company activities.

6. Jordanian tourism companies should provide technical support for users of hardware and software.

\section{References}

Abdullah, N. (2008). Applications of activity-based costing system in Yemeni industrial companies, unpublished Master Thesis, Yemen.

Abu hashish, K. (2005). Cost accounting, Wael publishing, Amman, Jordan.

Abu Nassar, M. (2010). Management accounting, Wael publishing, Amman, Jordan.

Atkinson. A. (2001). Management Accounting, 3ed Edition, prentice - hall, international Inc.

Carsten, H. (2003). Improving Activity-Based Costing Heuristics by Higher-Level Cost Drivers, European Journal Of Operational Research.

David, Ben-Arich, \& Li , Qian. (2003). Activity-Based Cost Management for Design And Development Stage, International Journal Of Production Economics, 83(2), 169-183. http://dx.doi.org/10.1016/S0925-5273(02)00323-7

Drury, C. (2000). Management \& cost Accounting, 5th ed, business prose and sons learning, (U. K).

Durgham, M. (2007). Availability of ingredients to apply activity-based costing system in public hospitals in the Gaza Strip, Journal of economic sciences and management, 23(1), $32-76$.

Garrison, R., Noreen, E., \& Brewer, P. (2006). Managerial Accounting. Mc Graw Hill Companies, New York, 7th Edition.

Helles, A. (2007). Activity-based costing system ABC as a basis for measuring the cost of educational services in Universities, Islamic University Journal (Humanities series), 15(1), 211-238. 


\section{Macrothink}

Journal of Management Research

ISSN 1941-899X 2012, Vol. 4, No. 2

Horngren, C., Foster, G., \& Datar. (2010). Cost Accounting: Managerial Emphasis. Fourteenth Edition. Prentice - Hall International, Newjersey. INC USA.

Katja, Tornberg. Et Al. (2002). Activity-Based Costing and Process Modeling For Cost-Conscious Product Design: A Case Study in A Manufacturing Company, International $\begin{array}{llll}\text { Journal of } & \text { Production } & \text { 75-82. }\end{array}$ http://dx.doi.org/10.1016/S0925-5273(00)00179-1

Mahmood, M. (2007). Activity-based costing system ABC in Palestinian Drugs firms, unpublished Master Thesis, Yemen.

Mari, Abdul Hai, \& others. (2002). Cost accounting developed for the purposes of planning and control, University House, Alexandria.

Nashar, T M. (2001). Proposed framework for the integration of cost accounting system based on the operations PBC and the accounting system cost based on the characteristics of the product $\mathrm{FBC}$, Journal of the Faculty of Commerce for scientific research, Faculty of Commerce, Alexandria University, 38.

Ragby, M. (2004). Management accounting, Wael publishing, Amman, Jordan.

Rihawi, M. (2006). The impact of "cost data and ways to reduce it" on pricing decisions, Administrative journal, 104, 78-79.

Victoria, Dickinson, \& John, C. Lere. (2003). Problems Evaluating Sales Representative Performance? Try Activity- Based Costing, Industrial Marketing Management, 32(4) ,301-307. http://dx.doi.org/10.1016/S0019-8501(02)00203-1 